\title{
Mandenkan
}

MANDENIKAN Bulletin semestriel d'études linguistiques mandé

$57 \mid 2017$

Numéro 57

\section{Basic morphosyntax of verbal and non-verbal clauses in San-Maka}

Le morphosyntaxe de base des phrases verbales et non-verbales en san-maka БАЗОВЫЙ МОРФОСИНТАКСИС ГЛАГОЛЬНЫХ И НЕГЛАГОЛЬНЫХ ПРЕДЛОЖЕНИЙ В

САН-МАКА

\section{Elena Perekhvalskaya}

\section{(2) OpenEdition}

Journals

\section{Electronic version}

URL: https://journals.openedition.org/mandenkan/1070

DOI: 10.4000/mandenkan.1070

ISSN: $2104-371 X$

\section{Publisher}

Llacan UMR 8135 CNRS/Inalco

\section{Electronic reference}

Elena Perekhvalskaya, "Basic morphosyntax of verbal and non-verbal clauses in San-Maka",

Mandenkan [Online], 57 | 2017, Online since 14 December 2017, connection on 08 July 2021. URL:

http://journals.openedition.org/mandenkan/1070 ; DOI: https://doi.org/10.4000/mandenkan.1070

This text was automatically generated on 8 July 2021.

\section{cc) (†) (2)}

Les contenus de Mandenkan sont mis à disposition selon les termes de la Licence Creative Commons Attribution - Pas d'Utilisation Commerciale - Partage dans les Mêmes Conditions 4.0 International. 


\title{
Basic morphosyntax of verbal and non-verbal clauses in San-Maka
}

\author{
Le morphosyntaxe de base des phrases verbales et non-verbales en san-maka \\ БАЗОВЫЙ МОРФОСИНТАКСИС ГЛАГОЛЬНЫХ И НЕГЛАГОЛЬНЫХ ПРЕДЛОЖЕНИЙ В \\ САН-МАКА
}

Elena Perekhvalskaya

1 This article presents an overview of the main verbal constructions of San-Maka, a Mande language of Burkina Faso. The article is structured as follows: the introduction provides general facts on San-Maka, its position in the San/Sane language cluster, and basic information on its phonetics and noun morphology. This is followed by a description of San verbal morphology and predicative constructions. In the final section, an overview of San-Maka non-verbal predications is given.

2 This article is based on language data gathered by the author during two field work sessions in Burkina Faso $(2016,2017)$, data from a published San-French dictionary (Boo $n \varepsilon n$ sÉwE) and Primer (Ka daa wつ); as well as on works on San-Maka by Suzy Platiel (1974) and Moïse Paré $(1998,1999)$.

\section{The San cluster}

3 Southern San (San-Maka) is a language of the Eastern group of theMande language family. It belongs to a dialect / language cluster known as San or Samo. Sometimes the term Sanan is used which represents a plural form of San. According to the Ethnologue, there were 233000 San speakers in 2009. This language is spoken almost exclusively in the provinces of Sourou (with the center in Tougan) and Nayala (with the center in Toma) in Burkina Faso.

4 The divisions within the cluster are subject to debate. The most popular proposal is a subdivision into three varieties: Maka in the South, Makya and Maya in the North. The 
northern region is smaller as well as much less homogenous from a linguistic point of view (Berthelette 2001: 5-7).

The names of the three varieties are based on the expression 'I say' in the respective varieties (Platiel 1974: 25). Traditionally in linguistic literature the northern varieties are referred to as Sane, with the term San designating the Southern dialect (see for example Vydrine, Bergman, Benjamin 2001), these labels were first proposed by André Prost (1981: 18). William Welmers (1958) expressed the idea that Northen and Southern San varieties are in fact different languages, as they are completely unintelligible, while Joseph Greenberg (1963: 8) apparently regarded all varieties of San as one language. The main difference of opinion on the subdivision of San concerns the opposition between southern and northern varieties, i.e. "the languages of Toma and Tougan"; they can be considered as one language (Greenberg), two dialects (Prost 1981) or three (Platiel 1974) of the same language, or as two different languages (Welmers 1958). Though Platiel refers to three dialects (Maka, Makya and Maya), she notes a clear cultural division, since "chacune de ces deux populations considère l'autre comme étrangère » (Platiel 1974: 25).

There is also debate concerning the names of these speech varieties. The San-French

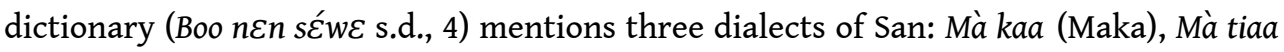
(Makya) and Mà yaa (Maya). Southern San, which includes the variant of Toma, is defined there as Mà kaa. The two new unpublished dictionaries by $\mathrm{SIL}^{1}$ are titled: Guide d'orthographe san macaa and Guide d'orthographe san mayaa, where he Macaa dialect corresponds to the Mà tiaa dialect mentioned in the San-French dictionary ${ }^{2}$.

Fig. 1. San varieties (Vydrine, Bergman, Benjamin 2001)

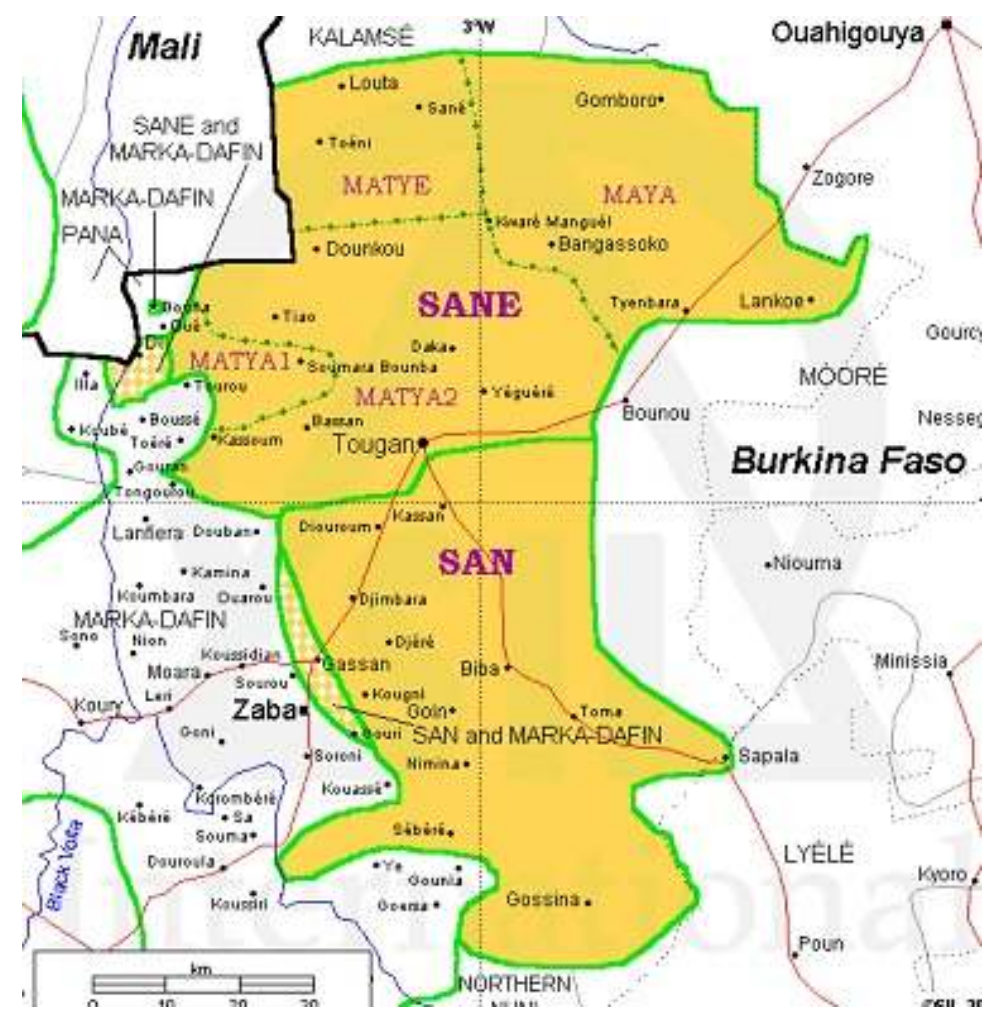

7 Linguists working on the San language cluster agree that compared to the northern speech varieties, the Southern part is most homogenous. In the area of San-Maka (or 
San as opposed to Sane) there are only minor differences among varieties. The description of nominal and verbal morphology by Moïse Paré $(1998,1999)$ was based on the Yaba variant of San-Maka, noting certain differences between Yaba and Toma varieties. Some of these differences are dealt with in this article.

The situation in the Northern area is more complicated. According to Erwin Ebermann, within Northern San four different "lects" can be distinguished. In addition to Maya (Ko on Ebermann's map) and Makya (Ba on the map), Ebermann notes a transitional variety: To which is situated between the Makya and Maya zones as well as the Fo variety localized in the North-West Sourou province near the border with Mali (Ebermann n.d.). San literacy workers consulted on this subject are rather skeptical on the relevance of this subdivision and insist on the existence of only three "official" San varieties, although they do mention significant cultural distinctions in the area where Ebermann's Fo variety is spoken.

Fig. 2 Northern San varieties according to Erwin Ebermann ${ }^{3}$

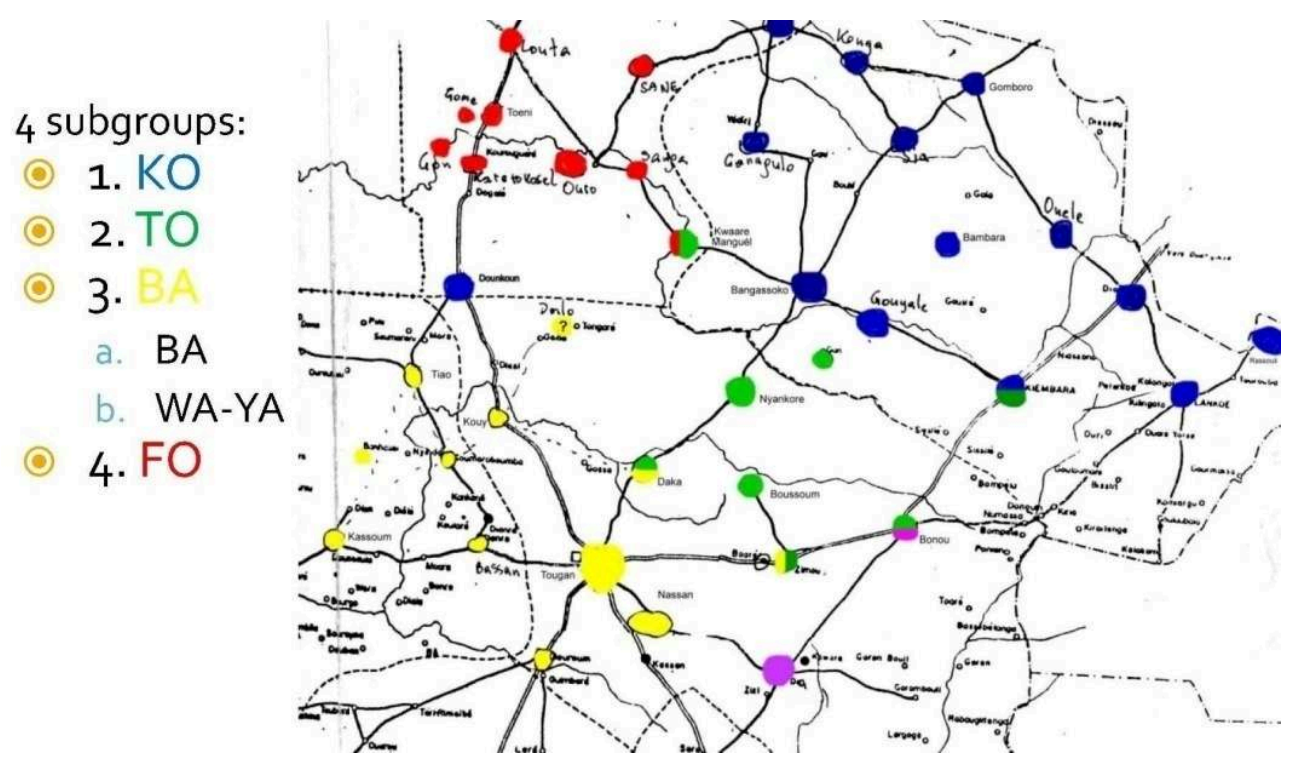

Suzy Platiel (1974: 24) mentions four varieties ("parlers") in the Makya zone: Daalo, Daale, Toa and Dya-kaso. Platiel and Ebermann agree that the Maya dialect on the North-East is quite homogenous. As for the Makya zone, it seems to be linguistically rather diverse including three or four different dialects.

Writing systems have been elaborated for three varieties: Maka, Maya and Makya. The written form of San-Maka is based on the variety spoken in Toma, the administrative centre of the Nayala province. In this paper, this will be the variety under study.

Table 1. Vowels

\begin{tabular}{|l|l|l|l|}
\hline & Front & Middle & Back \\
\hline Closed & & $\eta$ & \\
\hline High & $i \underset{\sim}{i}$ & & $u$ u \\
\hline Mid-high & $e \underset{\sim}{e}$ & $\partial$ & $o$ \\
\hline
\end{tabular}




\begin{tabular}{|l|l|l|l|}
\hline Mid-low & $\varepsilon \underset{\sim}{\varepsilon}$ & & ว 고 \\
\hline Low & & $a \underset{\sim}{a}$ & \\
\hline
\end{tabular}

\section{General information on the language}

\subsubsection{Phonetics}

11 The system of vowels in San-Maka is represented at the Table 1.

12 Comments:

13 1) Nasalization is a distinctive feature, oral phonemes /o/ and / $/$ / have no nasal counterparts. ${ }^{4}$

14 2) I regard "long vowels" as combinations of two identical vowels: pi

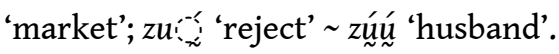

15 3) The phoneme $/ y /$ is classified as a vowel. Like other vowels, it is a tone-bearing unit.

Table 2. Consonants

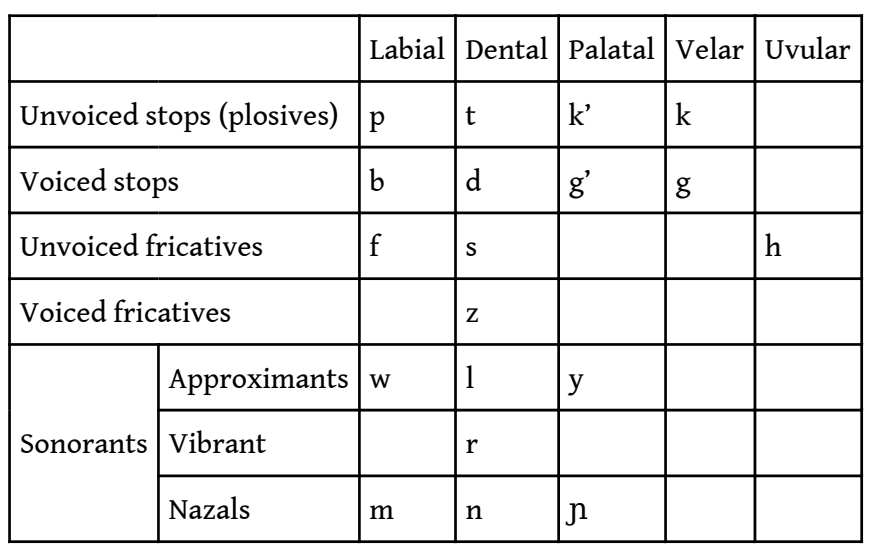

16 Comments:

17 1) The palatal consonants $/ \mathrm{k}^{\prime} /$ and $/ \mathrm{g}^{\prime} /$ may be pronounced as affricates $[\mathrm{t}]$ ] and [dz] or as palatals [k'] and [g'] respectively. Following San orthography, in this paper these sounds are spelled as $k i$ and $g i$, therefore, $k i o(\eta)^{5}$ 'house' may be pronounced as [k'o] or [t]o].

18 2) The floating nasal element $y$ : some words in San Maka have a stem final nasal element, which is normally not pronounced. These are mainly nouns, ${ }^{6}$ and also several adjectives and adverbs; it is not characteristic for verbs.

19 3) Vowel harmony affects vowel height: within one phonetic word, vowels can be either all mid-open $(0, \varepsilon)$ or mid-closed $(o, e)$.

20 An important phonetic feature in Maka that is unique among Mande languages is the existence of harmonic variants for two clitics and one bound morpheme. These are a

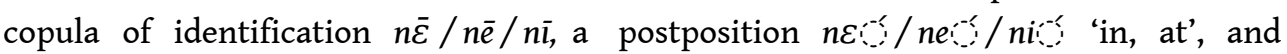


the allomorphs of the plural marker appearing after the $(-\eta)$ stems

-ní /-nə /né /-nó /-ná. The distribution of the varians is shown in Table 3.

Table 3. Distribution of synharmonic varians

\begin{tabular}{|c|c|c|c|c|}
\hline & & Copula of identification & Postposition 'in' & Plural marker \\
\hline \multicolumn{5}{|c|}{ Left context } \\
\hline High & $i, u$ & $n \bar{i}$ & ní & $n i ́$ \\
\hline & e & \multirow[b]{2}{*}{$n \bar{e}$} & \multirow[b]{2}{*}{ né } & \multirow[b]{2}{*}{ ná } \\
\hline Mid-high & $\partial$ & & & \\
\hline \multirow[t]{2}{*}{ Mid-low } & $\varepsilon, 0$ & \multirow{3}{*}{$n \bar{\varepsilon}$} & \multirow{3}{*}{ né } & $n \varepsilon ́$ \\
\hline & 0 & & & nó \\
\hline Low & $a$ & & & ná \\
\hline
\end{tabular}

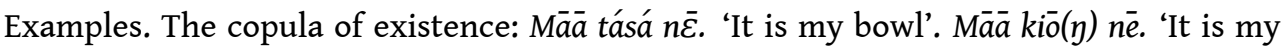
house'. Māà būūkūrù nì. 'It is my machete'.

The postposition 'in, at': làndā né 'in tradition', nò né 'in the stomach', kíwí gólé né 'in the city (lit.: in big village)', wù bósò né 'in the preparation of tô'; piii ní 'in the market', wù ní 'in tô'.

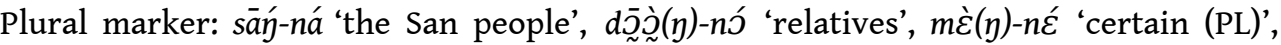

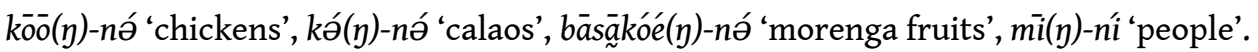

\subsubsection{Tonal system.}

San-Maka is a tonal language with three level tones, designated, according to IPA, by acute, macron and gravis diacritics. Tones in San-Maka play a role in both the lexicon and grammar. There are minimal pairs confirming the lexical function of tones (bálá 'individual field' bàlà 'stick'; pàa 'cheek pàa 'force') as well as their grammatical functions (e.g. in the verbal paradigm: 'to come' dāā, neutral form vs. dāà, perfective). In compound nouns, the tone of the second element is replaced by a higher one: $n \bar{\varepsilon}$

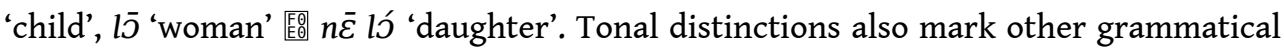
functions.

\subsection{Noun}

Nouns in San Maka may be divided into two classes: 1) those whose stems end with the floating nasal element $\eta ; 2$ ) all other words. There are minimal and quasi minimal pairs:

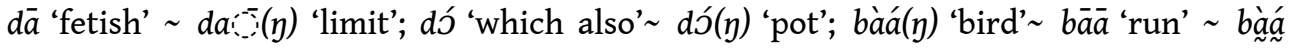


'place' etc. The floating nasal element of an NP affects the form of certain grammatical elements, which follow it, such as the plural marker and certain predicative markers.

Depending on the structure of the possessive nominal constructions, nouns are divided into two classes: free (alienable) and relational (inalienable). In a possessive group, free nouns require a possessive marker (possessive postposition) $\bar{a}$ : Kōodé a a kiō $(\eta)$ 'Kodé's house'. Relational nouns (terms for body parts, certain kinship terms) are used without this marker: Kōòdé gólógíi ‘Kodé’s elder brother’.

he form of the plural marker depends on the type of the noun or adjective stem.Words with - $\eta$ stems form the plural with a high-tone suffix -ná/-nó/-nó/-ní. The vowel is chosen according to the final vowel of the noun stem (see table 3). Other words form plurals by adding the suffix $-\eta y$ which carries a high tone if the stem has the structure $\mathrm{CV}$; otherwise it acquires the tone of the prevous syllable, cf. Table 4.

Table 4. The formation of noun plural in San-Maka:

\begin{tabular}{|c|c|c|}
\hline Singular & Translation & Plural \\
\hline só & 'tooth' & sóń \\
\hline tù & 'well' (for water) & tùn \\
\hline sèré & 'ram' & sèréń \\
\hline dòmō & 'griot' & dذ̀mō̄̄ \\
\hline tóó & ‘ear’ & tóón \\
\hline gòò & 'liver' & gòò̀ \\
\hline wòtòró & 'cart' & wotórón \\
\hline$k i \bar{o}(\eta)$ & 'house' & kiōȳná \\
\hline gó(y) & 'forest' & góńnó \\
\hline màn & 'thing' & mànná \\
\hline$k \grave{\varepsilon}$ & 'this' & kèń \\
\hline dó & 'which also' & dóń \\
\hline
\end{tabular}

\subsection{Personal pronouns}

Table 5. Personal pronouns and forms fused with predicative markers

\begin{tabular}{|l|l|l|l|l|l|l|l|l|}
\hline & $\begin{array}{l}\text { Affixed } \\
\text { element }\end{array}$ & $1 \mathrm{Sg}$ & $2 \mathrm{Sg}$ & $3 \mathrm{Sg}$ & $1 \mathrm{Pl}$ & $2 \mathrm{Pl}$ & $3 \mathrm{Pl}$ \\
\hline
\end{tabular}




\begin{tabular}{|c|c|c|c|c|c|c|c|c|}
\hline 1 & Basic & - & $m \bar{a}$ & $\bar{y}$ & $\grave{a}$ & $w \bar{~}$ & $k \bar{a}$ & $\grave{\eta}$ \\
\hline 2 & Imperative & & & $\bar{y}$ & & & Kà & \\
\hline 3 & Emphatic & $s \varepsilon$ & māsć & $\bar{y} s \varepsilon ́$ & àsé & wว̄sćń & kāsćń & $\grave{y} s \varepsilon \varepsilon^{\prime}$ \\
\hline 4 & Possessive & $\bar{a}$ & $m \bar{a} \bar{a}$ & $\bar{y}$ & $\grave{a}$ & $w \bar{\partial} \bar{a}(w \bar{a})$ & $k \bar{a} \bar{a}$ & $\grave{n}$ \\
\hline 5 & Imperfective & $n \bar{\partial} / \bar{y}$ & mā $\bar{y}$ & $\bar{y} n \bar{\partial}$ & $\grave{a} \bar{y}$ & wว̄̄ & $k \bar{a} \bar{y}$ & $\begin{array}{l}\text { mày } \\
\grave{y} n \bar{\partial}\end{array}$ \\
\hline 6 & $\begin{array}{l}\text { Imperfective } \\
\text { new information }\end{array}$ & tá /á & máá & $\bar{y} t a ́$ & $a ́ a ́$ & wóá & káá & $\grave{y}$ tá \\
\hline 7 & Imperfective Negative & $b \bar{a} / \bar{a}$ & $m \bar{a} \bar{a}$ & $\bar{y} b \bar{a}$ & $\grave{a} \grave{a}$ & $w \bar{\jmath}$ & $k \bar{a} \bar{a}$ & $\grave{y} b \bar{a}$ \\
\hline 8 & Perfective & ná / high tone & má & $\underline{n}$ & $a ́$ & wó & ká & ̀̀ ná \\
\hline
\end{tabular}

There are six personal pronouns. Personal pronouns fuse with certain predicative markers and also with the possessive marker $\bar{a}$. Most of these forms can be easily decomposed: this is true for Emphatic, Imperfective habitual (with the exception of the $3 \mathrm{Pl}$ form) and Imperfective negative forms.

Comments to the Table 5:

1) The forms are written in one or two words according to the orthographic tradition. Emphatic pronouns, which are predictable, could be written in two words if one postulates the existence of a determinant sć (which has a regular plural form sćń).

2) Series 5-8 result from fusion of basic pronouns with predicative markers; together with corresponding verbal forms they constitute predicative constructions in the absence of a full-fledged subject.

3) The $3 \mathrm{Pl}$ pronoun optionally forms a compound mày with the Imperfective habitual PM $n \bar{\partial} / \bar{y}$. However, a non-fused variant $\grave{\eta} n \bar{\partial}$ is also attested in my data and also in written texts (Syllabaire 2003). The element mà is a competing $3 \mathrm{Pl}$ form which appears also with the copula of identification ( $3 \mathrm{Pl}$ form mànes) and with postpositions (e.g. ká mànć 'with them', where ká is a comitative preposition).

4) The Imperative is characterized by a special $2 \mathrm{Pl}$ form with a low tone $(k \dot{a})$ which is not used in prohibitive constructions where the mid-tone subject $2 \mathrm{Pl}$ form is used $(k \bar{a})$.

5) Possessive pronouns, which are used with free nouns, have special forms only for $1 \mathrm{Sg}, 1 \mathrm{Pl}$ and $2 \mathrm{Pl}$.

\subsection{Word order}

San Maka has a strict word order. Like other Mande languages, it has the following linear sequence of elements:

Order of elements in the genitive and possessive constructions is as follows:

Noun Modifier (Possessor) - modified (Possessee) 


\title{
2.5. Adpositions
}

41 'with' (used in combination with the postposition $n \varepsilon / n e / n i$ ).

\section{Verbs}

\begin{abstract}
expressing aspect, tense, modality and polarity.
\end{abstract} of a clouse and which form, alon

The verb is inflected for aspect and mood.

\subsection{Verbal morphology}

The morphological paradigm of a verb in San-Maka consists of three aspectual forms: neutral, perfective and imperfective. In non-indicative forms, aspectual meanings are not expressed, and the verb is represented by a neutral form. This form also appears in the negative perfective construction. The neutral form is used as the basic form in dictionaries and linguistic works. ${ }^{7}$

Table 6. Sample verbal forms

\begin{tabular}{|c|c|c|c|}
\hline & Neutral form & Perfective & Imperfective \\
\hline 'to eat' & $b \overline{i i}$ & $\overrightarrow{b i i}$ & $b \overline{i i}$ \\
\hline 'to come' & $d \bar{a} \bar{a}$ & $d \bar{a} a ̀$ & $d i \bar{e}$ \\
\hline 'to strike, to kill' & $d \bar{\varepsilon}$ & $d \bar{\varepsilon}$ & díi \\
\hline 'to send' & diā & dià & dić \\
\hline 'to teach' & dórōo & dōròo & dōrêe \\
\hline 'to hide' & dúrū & dūrù & dúri \\
\hline 'to stay' & $g \bar{Q} \bar{\alpha} \bar{\alpha}$ & gò $\underset{\alpha}{\alpha}$ & $g \bar{Q} \bar{\sim} \bar{\sim}$ \\
\hline
\end{tabular}

Both perfective and imperfective forms seem to be derived from the non-finite verb forms (nominalizations or gerunds). Perfective forms historically seem to be formed with the help of a low tone suffix (or postposition); imperfective forms are formed through the addition of a suffix $-e /-\varepsilon$. The neutral form seems to be etymologically simple. 

raise the tone of the first syllable in the presence of a direct non-pronominal object. See the neutral form used in Imperative (1) and in Conjunctive (2) constructions.

\begin{tabular}{|l|l|l|l|}
\hline$(1)$ & Kà & wù & bií. \\
\hline & 2PL.IMP & tồ & eat $/ \mathrm{H}$ \\
\hline
\end{tabular}

'(You, pl.) eat tồ'.

\begin{tabular}{|l|l|l|l|l|l|l|}
\hline$(2)$ & $\grave{y}$ & $p \grave{\varepsilon}$ & $m \grave{a}$ & Kōōdé & wù & bií. \\
\hline & 2SG.PFV & say.PFV & that & Koode & tô & eat/H \\
\hline
\end{tabular}

'You (sg.) ordered that Koodé would eat tô'.

The neutral form of the verb bii 'to eat' carries a mid tone, but with an overtly expressed direct object, the tone of the verb becomes high. This tone modification does not occur with the imperfective form of the same verb, which keeps its mid tone (3).

\begin{tabular}{|l|l|l|l|l|}
\hline (3) & Mã & $\bar{y}$ & wù & $b \overline{u i .}$ \\
\hline & SG & IPFV & tô & eat.IPFV \\
\hline
\end{tabular}

'I eat tô'.

\subsection{Predicative markers}

51 Perfective and imperfective verb forms combine with predicative markers, some of which seem derived from corresponding copulas (see 5.2.).

52 Predicative markers form a separate word class in San-Maka. They occupy the position after the Subject NP.

Table 7. Predicative markers

\begin{tabular}{|l|l|}
\hline Perfective affirmative & $\begin{array}{l}\text { ná / high tone on the final vowel of the } \\
\text { Subject NP }\end{array}$ \\
\hline Perfective negative & $n \bar{\partial} / \varnothing$ \\
\hline Perfective experiential & $b \bar{c} \bar{y}$ \\
\hline Imperfective affirmative & $n \bar{\partial} / \bar{y}$ \\
\hline Imperfective affirmative "new information" & tá $/ a ́$ \\
\hline
\end{tabular}




\begin{tabular}{|l|l|}
\hline Imperfective negative & $b \bar{a} / \bar{a}$ \\
\hline $\begin{array}{l}\text { Imperfective negative in dependent clauses, } \\
\text { prohibitive }\end{array}$ & bārày \\
\hline
\end{tabular}

\begin{tabular}{|l|l|l|l|}
\hline$(5)$ & Bòé & lé & dāà. \\
\hline & goat & ART $\backslash \mathrm{PFV}$ & come.PFV \\
\hline
\end{tabular}

\subsubsection{The experientive perfective PM bì}

59 experientive perfective PM bì may be used in affirmative, interrogative and negative contexts. Affirmative and interrogative sentences require the perfective verb form (6-8); in negative contexts, the neutral verb form is used (9).

\begin{tabular}{|l|l|l|l|l|l|}
\hline$(6)$ & $L \bar{\jmath}$ & lè & bì̀ & bòe & sā. \\
\hline & woman & ART & PFV.EXP & goat & sell.PFV \\
\hline
\end{tabular}

'The woman has already sold the goat (has the experience)' (Paré 1998: 33). 


\begin{tabular}{|c|c|c|c|c|c|}
\hline (7) & $L \bar{\partial}$ & lı̀ & bì̀ & $d \bar{a} a ̀$ & kānā \\
\hline & woman & ART & PFV.EXP & come.PFV & here \\
\hline
\end{tabular}

‘The woman has already come here' (Paré 1998: 33).

\begin{tabular}{|l|l|l|l|l|}
\hline$(8)$ & $\bar{y}$ & bín & nànsáárá & $y \bar{\varepsilon} ?$ \\
\hline & 2SG & PFV.EXP & European & see.PFV \\
\hline
\end{tabular}

'Have you ever seen a white person?'

\begin{tabular}{|l|l|l|l|l|l|}
\hline$(9)$ & $M \bar{a}$ & $b \bar{i} \bar{y}$ & $y \bar{\nu}$ & $m i ́$ & $w \bar{a}$. \\
\hline & 1SG & PFV.EXP & beer & drink.NTR/H & NEG \\
\hline
\end{tabular}

63 'I have never drunk beer'.

64 M. Paré (1998: 36) singles out two different PMs, bi and bì̀: bì̀ in affirmative sentences, and $b_{\sim} i . . . w \bar{a}$ in negative sentences. My informants do not distinguish between these forms; probably this fact reflects the difference between Yaba and Toma variants. In my data, a variant bini of this PM has been attested:

\begin{tabular}{|c|c|c|c|c|c|c|c|c|c|c|}
\hline (10) & $M \bar{a}$ & bini & $z \overline{i i}$ & tō & wó & woo & b’àá & kón & $n \bar{\varepsilon}$ & wà. \\
\hline & $1 \mathrm{SG}$ & PFV.EXP & road & walk & do & go & place & any & in & NEG \\
\hline
\end{tabular}

'I have never gone anywhere'.

\subsubsection{Perfective negative PM n̄̄ /ø}

67 Perfective negative PM $\boldsymbol{n} \overline{\boldsymbol{\theta}} / \boldsymbol{\emptyset}$ is represented by a null (11) unless it appers after a plural NP or one ending with- $\eta(12)$ :

\begin{tabular}{|l|l|l|l|l|}
\hline$(11)$ & $L \bar{\jmath}$ & gōa & píi-n & wā. \\
\hline & woman & remain & market-in & NEG \\
\hline
\end{tabular}

'A woman did not stay in the market'.

\begin{tabular}{|l|l|l|l|l|}
\hline$(12)$ & $M \bar{i}(\eta)$ & $n \bar{\partial}$ & $d \bar{a} \bar{a}$ & $w \bar{a}$. \\
\hline & person & PRF.NEG & come & NEG \\
\hline
\end{tabular}


'Nobody has come'.

\subsubsection{Imperfective PMs}

\begin{tabular}{|c|c|c|c|c|c|}
\hline (13) & $L \bar{\nu}-\bar{\eta}$ & $l \grave{\varepsilon}-\grave{n}$ & tá & bòé & $\bar{S} I \bar{\alpha} \overline{\underline{\varepsilon}}$. \\
\hline & woman-PL & ART.PL & IPFV.NEW & goat & sell.IPFV \\
\hline
\end{tabular}

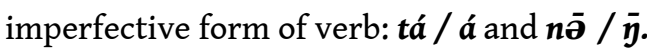
compte de la différence » (Platiel 1974: 570-571). to the habitual domain (« une vérité ou une opinion »).

There are two predicative markers of the affirmative polarity, which require the

The interpretation of verbal structures with these PM has been a matter of discussion. Translations of individual sentences are often misleading as they allow different interpretations. Isolated phrases (e.g. proverbs) do not clear up the situation. Researchers of the San-Maka language, Suzy Platiel (1974) and Moise Paré (1998), expressed different opinions about the meaning of these forms.

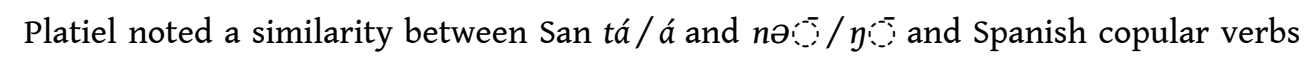
ser and estar. As a result, she attributed the same meanings to the San copulas: «.../ ta / se traduit par "ser". Cette forme sera donc utilisée, de préférence à l'autre, toutes les fois que l'on souhaitera asserter une qualité, un état, un événement, ou une situation dont le caractère est considéré comme irrévocable, ou plus simplement, quand on ne souhaite pas mettre l'accent sur son aspect provisoire... Le prédicat de forme complète $/ \mathrm{n} \bar{\varepsilon} /[$ [...] par opposition au précédent correspondrait à "estar"; il situe l'événement en introduisant une notion de relativité à la fois temporelle et spatiale » (Platiel 1974: 570). Thus, according to Platiel, the imperfective constructions of San-Maka are contrasted by the permanent or temporary characteristics of properties, qualities and situations. Unfortunately, Platiel does not provide convincing examples to prove her hypothesis. She wrote: « Dans tous les exemples cités ci-dessus, / a / pourrait être remplacé par $/ \bar{\sim} / 10$; la traduction française ne pouvant pas rendre

M. Paré proposed an aspectual interpretation for the opposition between the two quasisynonymous constructions. He attributes the habitual meaning to the constructions with the PM tá/á, and the progressive meaning to the constructions with the PM $n \bar{\partial} / \bar{y}$ (Paré 1998: 37, 47). However, further on (p. 61) he writes: "La valeur secondaire du prédicatif ta $[. .$.$] est celle du progressif. Ici le procès en cours de réalisation au$ moment de l'énonciation...". At the same time, it is stated for the PM $\bar{\eta}$ that : «En plus de sa valeur progressive, $\bar{y}$ est aussi le prédicatif qui est utilisé pour relater une vérité ou une opinion" (Paré 1998: 63). Thus, there is an uncertainty in his distribution of aspectual meanings between both constructions: the progressive meaning is ascribed to constructions with both PMs; and both constructions express meanings, which belong

\section{Cf. examples with different PMs expressing the progressive aspectual meaning:}

\begin{tabular}{|l|l|l|l|l|l|}
\hline$(14)$ & $M \bar{a}$ & $\overline{\mathfrak{y}}$ & wù & biii & sísià. \\
\hline
\end{tabular}




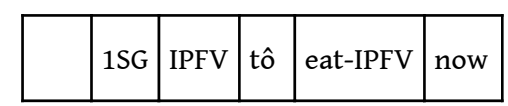

'I am eating tô'.

77 In the following examples habitual actions (15-16) or "eternal truths" (17-18) are expressed by both constructions.

\begin{tabular}{|c|c|c|c|c|c|}
\hline (15) & $L \bar{\nu}$ & $l \grave{\varepsilon}$ & $\bar{y}$ & bòé- $\eta$ & sid \\
\hline & woman & ART & IPFV & goat-PL & sell.PFV \\
\hline
\end{tabular}

'The woman sells goats'.

\begin{tabular}{|l|l|l|l|l|l|}
\hline$(16)$ & $\bar{y}$ & $t a ́$ & $m u ́$ & $b \overline{b i ̀}$ & dò̀̇. \\
\hline & 2 2SG & IPFV.NEW & water & run.PFV & know-IPFV \\
\hline
\end{tabular}

'You can swim'.

\begin{tabular}{|c|c|c|c|c|c|}
\hline (17) & $L \bar{~}$ & sōyböre & $\overline{\boldsymbol{y}}$ & sūmù & kóc̀. \\
\hline & woman & good & IPFV & yard & put.IPFV \\
\hline
\end{tabular}

'A good woman takes care of her yard' (Syllabaire 1: 16).

\begin{tabular}{|l|l|l|l|l|}
\hline$(18)$ & $L \bar{\varepsilon}$ & $a$ & gònó(y) & ziżi̇ič \\
\hline & mouth & IPFV.NEW & body & spoil.IPFV \\
\hline
\end{tabular}

81 'The mouth spoils the body' (proverb "words may harm").

82 My data show that these quasi-synonymous constructions encode different pragmatic intentions of the speaker. Constructions with $n \bar{\partial} / \bar{y}$ point out at a "general state of affairs"; constructions with tá / á encode information that is supposed to be new to the listener. ${ }^{11}$

83 See the following examples:

\begin{tabular}{|l|l|l|l|l|}
\hline (19) & Bòé & $\bar{y}$ & būū & s̄̄̄ $\bar{c}$. \\
\hline & sheep & IPVF & grass & eat.IPFV \\
\hline
\end{tabular}

84 'A sheep eats grass' (general information of the usual behavior of sheep). 


\begin{tabular}{|l|l|l|l|l|}
\hline$(20)$ & Bòé & tá & būū & sō̄ $\bar{\sim}$. \\
\hline & sheep & IPVF.NEW & grass & eat.IPFV \\
\hline
\end{tabular}
eggs?"

\subsubsection{Imperfective $P M$ nō / $\bar{y}$ (3 Pl màỳ)}

91

\begin{tabular}{|l|l|l|l|l|l|l|l|}
\hline (23) & Mā & $\grave{y}$ & gíćli & màá & Kōōdé & wù & búii. \\
\hline & 1SG & IPFV & look.for.IPFV & that & Koodé & tô & eat/H \\
\hline
\end{tabular}




\begin{tabular}{|l|l|l|l|l|}
\hline (25) & Mà̀ & wù & bósè & lōy? \\
\hline & 3PL.IPFV & tô & cook.IPFV & how \\
\hline
\end{tabular}




\begin{tabular}{|l|l|l|l|l|l|l|l|l|}
\hline$(29 b)$ & $M \bar{a}$ & $n \bar{\partial}$ & dõé $_{\sim}$ & mà & $\bar{y}$ & wóó & púi & ní. \\
\hline & 1 SG & IPFV & know.IPFV & that & 2SG & go & market & in \\
\hline
\end{tabular}

'I know that you go to the market' (in spite of the fact that you did not tell me).

\subsubsection{Imperfective negative $P M b \bar{a} / \bar{a}$}

In the imperfective negative, the distinction between both affirmative imperfective constructions is neutralized; the only negative PM is $b \bar{a} / \bar{a}:$

\begin{tabular}{|l|l|l|l|l|l|l|l|}
\hline$(30)$ & $L \bar{\jmath}$ & $l \grave{\varepsilon}$ & $b \bar{a}$ & $b \grave{e ́}$ & $l \grave{\varepsilon}$ & $\bar{s} \bar{c} \overline{\mathcal{E}}$ & $w \bar{a}$. \\
\hline & woman & ART & IPFV.NEG & goat & ART & sell.IPFV & NEG \\
\hline
\end{tabular}

107 'The woman is not selling the goat'.

108 It is also used in proverbs (31) and for negating habitual (32) actions.

\begin{tabular}{|l|l|l|l|l|l|l|}
\hline$(31)$ & Gōy & góōy & $b \bar{a}$ & wùsú & góè & wà. \\
\hline & hand & one & IPFV.NEG & flour & gather.IPFV & NEG \\
\hline
\end{tabular}

'One hand does not gather the flour' (a proverb) (Syllabaire 1:34).

\begin{tabular}{|l|l|l|l|l|}
\hline$(32)$ & $M \bar{a}$ & $\bar{a}$ & d’̀ $\bar{c}$ & $w \bar{a}$. \\
\hline & 1SG & IPFV.NEG & know.IPFV & NEG \\
\hline
\end{tabular}

110 'I don't know'.

111 Negative constructions with $b \bar{a} / \bar{a}$ can negate prospective situations:

\begin{tabular}{|l|l|l|l|l|l|l|l|}
\hline (33) & Díé & $n \bar{e} ?$ & Mā & $\bar{a}$ & $\overline{p i i}$ & nì & wā. \\
\hline & who & ICOP & 1SG & IPFV.NEG & say.IPFV & in/L & NEG \\
\hline
\end{tabular}

112 'Who is this? I won't tell to anybody'.

\subsubsection{The imperfective negative contrastive element bỉe}

113 The imperfective negative contrastive element biè, according to Paré (1998), has the experiential meaning "I have never"; in my data it appears only in the sentences of identification ${ }^{12}$ (see 5.2.2). 


\subsubsection{Prohibitive PMs}

114 Moïse Paré (1998: 53-54) mentions two prohibitive PMs: $\eta \bar{a} \ldots w \bar{a}$ and bārà ... wā. According to his description, $y \bar{a} . . . w \bar{a}$ is used more often then bārà ... wāa at the same time, these PMs express different meanings: $\eta \bar{a} \ldots w \bar{a}$ is the "negation of the imperative", and bārà ... wa is the negation of "énoncés injonctifs". In my materials (Toma variant) the PM bārày ... wa is the only construction available, both in prohibitive sentences (34-35) and with the negated dependent predication (36).

\begin{tabular}{|l|l|l|l|l|}
\hline$(34)$ & $\bar{y}$ & bārày & $w \bar{\jmath}$ & $w \bar{a}$. \\
\hline & $2 S G$ & PROH & enter & NEG \\
\hline
\end{tabular}

115 'Do not enter!' (prohibition).

\begin{tabular}{|l|l|l|l|l|l|l|}
\hline (35) & Kā & bārày & $p \grave{\varepsilon} r \bar{\varepsilon}$ & $m u ́$ & $m i ́$ & wa. \\
\hline & 2PL & PROH & lake & water & drink/H & NEG \\
\hline
\end{tabular}

116 'Do not drink the water from a pond! (advice addressed to more than one person)' (Syllabaire 2: 15).

\begin{tabular}{|c|c|c|c|c|c|c|c|c|}
\hline (36) & $\bar{\eta}$ & dōāmáá & $n \bar{\varepsilon}$ & $\bar{y}$ & bärày & sigārēèti & $m i$ & $w \bar{a}$. \\
\hline & $2 S G$ & necessity & ICOP & $2 S G$ & NEG & cigarette & drink & NEG \\
\hline
\end{tabular}

117 'You should not smoke (lit. It is necessary that you would not smoke)'.

\subsection{Auxiliaries}

In San-Maka, there is a closed class of words, which occupy the third position in the clause, after the predicative marker and before the direct object in transitive clauses or before the verb in intransitive ones. These words will be referred to as "auxiliaries". These are: tón - Continuative marker (affirmative context)

tòy - Continuative marker (negative context)

$121 \quad \bar{e}$ - Future marker

\subsubsection{Continuative markers}

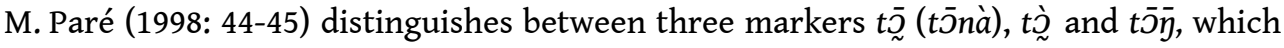
are used in different contexts: t⿳亠丷厂 (tว̄nà) «indique l'aspect continuatif du procès exprimé et est traduisable en français par "toujours", "encore" ou l'anglais "still” ». Tٍِ is used in negative clauses "pour signifier que le procès n'est pas encore effectif au 
moment de l'énonciation ». The auxiliary tō̄̄ « est utilisé pour marquer qu'un procès est postérieur à un autre procès ».

In my data, the distinction between these forms is only tonal. In affirmative clauses, the auxiliary tōy (mid tone) is used in combination with the imperfective PMs $n \bar{\partial} / \bar{\eta}$ and tá / á (37). The high-toned tón is used as a discursive marker 'then' (38). The low-toned auxiliary tòy appears in negative clauses (39).

\begin{tabular}{|c|c|c|c|c|c|c|c|}
\hline (37) & $M \bar{a}$ & diić-giii & $\bar{y}$ & (á) & $t \bar{\partial} \eta$ & $d i$ & лع́. \\
\hline & $1 \mathrm{SG}$ & younger-brother & IPFV & (IPFV.NEW) & AUX & work & do.IPFV \\
\hline
\end{tabular}

(He has to stop working at a fixed time but) 'My younger brother is still working'.

\begin{tabular}{|c|c|c|c|c|c|c|c|}
\hline (38) & $A$ & kذे & là, & $a ́$ & tón & $p \grave{\varepsilon}$ & $n \grave{\varepsilon}^{13}$ \\
\hline & 3SG.PRF & give.PRF/L & on/L & 3SG.PRF & AUX & say.PRF & in/L \\
\hline
\end{tabular}

'He gave it to him and said to him'.

\begin{tabular}{|l|l|l|l|l|l|}
\hline$(39)$ & Mā & t’̀y & wóró & $y \bar{\varepsilon}$ & wā. \\
\hline & 1SG & not.yet & money & see/H & NEG \\
\hline
\end{tabular}

'I haven't obtained any money yet'.

127 M. Paré gives an example of the complex PM+AUX $(\underset{\sim}{i}+t \underset{\sim}{)}$ which expresses the experiential meaning:

\begin{tabular}{|l|l|l|l|l|l|l|}
\hline$(40)$ & Mā & bì & tò & wò & Bígia & wā. \\
\hline & 1SG & PFV.EXP & not.yet & go & Abidjan & NEG \\
\hline
\end{tabular}

'I have never been to Abidjan'.

\subsubsection{The future auxiliary rē}

The future auxiliary rē co-occurs with the Imperfective PMs tá / $a$ (affirmative) or $b \bar{a} / \bar{a}$ (negative):

\begin{tabular}{|l|l|l|l|l|l|l|l|l|}
\hline$(41)$ & $L \bar{j}$ & lì & $a$ & á & wé & Làwà & $\bar{a}$ & kiō(y). \\
\hline & woman & ART & IPFV.NEW & FUT & enter.IPFV & God & POSS & house \\
\hline
\end{tabular}

'This woman will enter the church'. 


\begin{tabular}{|l|l|l|l|l|l|}
\hline$(42)$ & Bòyó(y) & $b \bar{a}$ & $\bar{e}$ & dìe & $w \bar{a}$. \\
\hline & Boyo & IPFV.NEG & FUT & come.IPFV & NEG \\
\hline
\end{tabular}

'Boyo will not come'.

\subsection{Auxiliary verbs}

There are auxiliary verbs, which, from the syntactic point of view, behave as the verbal parts of the predicative constructions being heads of a verb chain. These are gōa $(g \bar{\alpha} \bar{\alpha} a \bar{a}$,

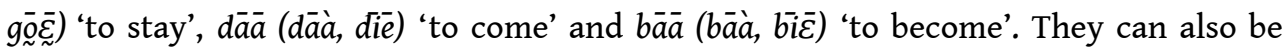
used as ordinary verbs with their primary lexical meaning.

\subsection{1. gōā}

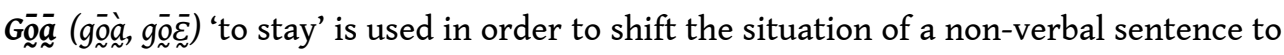
past or future, thus the non-verbal sentence becomes a verbal one.

134 In verbal sentences, gō $\bar{\alpha} \bar{a}$ is a marker of retrospective shift (which indicates that the action has lost its relevance):

\begin{tabular}{|c|c|c|c|c|c|c|c|}
\hline (43) & LÉĺर́ & má & gọda & bōé & sร́wう̀ & $k^{\prime} I \bar{E} \bar{E}$ & la. \\
\hline & before & 1SG.PFV & stay.PFV & can.IPFV & paper & write & on \\
\hline
\end{tabular}

'Formerly I could write (and now I cannot any more)'. ${ }^{14}$

\subsubsection{The imperfective form of the verb dāā}

The imperfective form of the verb dāa 'to come' > die is used to mark the immediate future; it co-occurs with the PM n̄̄ / $\bar{y}$ :

\begin{tabular}{|l|l|l|l|l|l|}
\hline$(44)$ & $M \bar{a}$ & $\grave{y}$ & die & sîi & kúkúri. \\
\hline & ISG & IPFV & FUT.PROX & meat & slice.IPFV \\
\hline
\end{tabular}

137 'I am going to cut meat'.

\subsubsection{The perfective form of the verb bāa}

138 The perfective form of the verb $b \bar{a} \bar{a}$ 'to become > bàa together with the future marker re expresses the avertive meaning (the action that "almost happened" or "nearly happened"). ${ }^{15}$

\begin{tabular}{|l|l|l|l|l|}
\hline$(45)$ & $A$ & $b \bar{a} a ̀$ & rè & gííc. \\
\hline
\end{tabular}


'He nearly died'.

\begin{tabular}{|l|l|l|l|l|l|l|l|}
\hline (46) & Tōetóá & bàa & $\bar{e}$ & $m \bar{\varepsilon} n \bar{\varepsilon} \bar{\varepsilon}$ & gúnúy & zii & $k a ́$ \\
\hline & Toetoa.PRF & become.PRF & FUT & fall.IPFV & yesterday & road & COMIT \\
\hline & mótó & né. & & & & \\
\hline & motorcycle & in & \multicolumn{3}{|l}{} \\
\hline
\end{tabular}

140 'Toetoa nearly fell down on the road with his motorcycle yesterday'.

\section{The basic verbal constructions. Indicative}

\subsection{Affirmative Perfective}

Affirmative Perfective PM nó / high tone on the Subject NP + perfective form of the verb

\begin{tabular}{|l|l|l|l|l|l|l|}
\hline (47) & Ló-y & nó & wōò & kòè & góè & dōy. \\
\hline & woman-PL & PFV & go.PFV & shea.nut & gather.IPFV & bush \\
\hline
\end{tabular}

'Women have gone to gather shea nuts in the bush'.

\begin{tabular}{|l|l|l|l|}
\hline$(48)$ & Né & ànānáà & nà. \\
\hline & child $\backslash P F V$ & pineapple & cut.PFV \\
\hline
\end{tabular}

'The child has cut a pineapple'.

\subsection{Negative Perfective}

Negative Perfective PM nō / 0 + neutral form of the verb and the negative particle wā at the end of the sentence

S nō / ø (DO) V.NTR ... wā

\begin{tabular}{|l|l|l|l|l|}
\hline$(49)$ & $\operatorname{Mi}(\mathfrak{y})$ & nō & dāā & wā. \\
\hline & person & AC.NEG & come.NTR & NEG \\
\hline
\end{tabular}




\begin{tabular}{|l|l|l|l|l|l|}
\hline$(50)$ & $\grave{A}$ & $\varnothing$ & sćwò & d’̀ & wā. \\
\hline & 3SG & PFV.NEG & paper & know.NTR & NEG \\
\hline
\end{tabular}

'He has not learned to read and write' (lit.: he has not learned the paper).

\subsection{Perfective experiential affirmative}

Perfective experiential affirmative bìn (bini) + Perfective form of the verb, see examples (7-9):

S bì (DO) V.PFV

\subsection{Perfective experientive negative}

Perfective experientive negative bì (bini) + neutral form of the verb and the negative particle $w \bar{a}$ at the end of the sentence; see examples (10-11):

S bì (DO) V.NTR ... wā

\subsection{Imperfective Affirmative}

Imperfective Affirmative PM $n \bar{\partial} / \bar{\eta}+$ imperfective form of the verb:

$\mathrm{S} n \bar{\partial} / \bar{y} /$ mà̀ (DO) V.IPFV

These constructions are often used in proverbs and in the expressions of "eternal truth":

\begin{tabular}{|l|l|l|l|l|l|l|}
\hline$(51)$ & $L \bar{\varepsilon}-d \bar{\varepsilon} n \bar{a} \bar{a}$ & $\bar{a}$ & sùi & $\eta$ & $b \bar{a} \bar{a}$ & síi. \\
\hline & mouth-owner & POSS & horse & IPFV & run & take.IPFV \\
\hline
\end{tabular}

'The horse of a phrasemonger runs fast' (Syllabaire 2: 9).

\subsection{Imperfective Affirmative (New Information)}

Imperfective Affirmative (New Information) PM tá /á + imperfective form of the verb:

S tá / á (DO) V.IPFV

\begin{tabular}{|c|c|c|c|c|c|}
\hline (52) & $L \bar{\nu}-\bar{\eta}$ & tá & kذ̀n & mîi & tî. \\
\hline & woman-PL & IPFV.NEW & RECP & head & weave.IPFV \\
\hline
\end{tabular}


'Women are doing each other's hair'.

\begin{tabular}{|c|c|c|c|c|}
\hline (53) & $L \bar{\jmath}-\bar{y}$ & $l \grave{\varepsilon}-\grave{\eta}$ & tá & dìè. \\
\hline & woman-PL & ART-PL & IPFV.NEW & come.IPFV \\
\hline
\end{tabular}

'Women are coming'.

\subsection{Imperfective negative}

Imperfective negative PM $b \bar{a} / \bar{a}+$ imperfective form of the verb + particle wā:

$\mathrm{S} b \bar{a} / \bar{a}(\mathrm{DO}) \mathrm{V.IPFV} \ldots w \bar{a}$

\begin{tabular}{|l|l|l|l|l|l|l|}
\hline$(54)$ & $M \bar{a}$ & $\bar{a}$ & mán & $k o ́ n$ & $d \grave{\nu} \overline{\bar{c}}$ & wā. \\
\hline & 1 SG & IPFV.NEG & thing & any & know.IPFV & NEG \\
\hline
\end{tabular}

163 'I know nothing'.

\subsection{Future}

Future marker $\overline{r e}\left(r_{e}\right)$ with the imperfective New Information construction, ${ }^{16}$ see examples (41-42):

Affirmative:

S tá /árē (DO) V.IPFV

Negative:

$\mathrm{S} b \bar{a} / \bar{a} r \bar{e}(\mathrm{DO}) \mathrm{V} . \mathrm{IPFV} \ldots w \bar{a}$

\section{Non-verbal sentences in San.}

Non-verbal sentences in San-Maka are those which do not contain a verbal lexeme in the Neutral form or in the forms of Perfective or Imperfective. The bearers of predication are the copulas. The following elements are used as copulas:

170 1) copulas which are used as predicative markers (both polarities);

2) postpositional copulas: the copulas of existence and the copula of identification.

\subsection{Copulas}

172 Copulas etymologically seem to be the source for the imperfective predicative markers of both polarities; they coincide with the latter both in form and meaning. The copula $n \bar{\partial} / \bar{y}$ encodes the general state of affairs, and tá / á point out at the new information: 


\begin{tabular}{|c|c|c|c|c|}
\hline (55) & $n$ & tá & pií & ní. \\
\hline & 3PL & COP.NEW ${ }^{17}$ & market & in \\
\hline
\end{tabular}

'They are now in the market (the answer to the question "Where are they?")'.

\begin{tabular}{|l|l|l|l|}
\hline (56) & Mà̀ & pí & ní. \\
\hline & 3PL.COP & market & in. \\
\hline
\end{tabular}

'They are in the market (state of affairs)'.

\begin{tabular}{|l|l|l|l|l|l|}
\hline (57) & Kiéylé & $k \grave{\varepsilon}$ & á & kóó & sísía. \\
\hline & door & this & COP.NEW & open & now \\
\hline
\end{tabular}

'(Look), this door is now open'.

\begin{tabular}{|l|l|l|l|l|l|}
\hline (58) & Kiéylé & mày & kóó & dúdúú. & \\
\hline & door & 3PL.COP & open & always & \\
\hline
\end{tabular}

'Doors are always open'.

In negative constructions $b \bar{a} / \bar{a}$ is used:

\begin{tabular}{|l|l|l|l|l|l|l|l|}
\hline (59a) & $L \bar{j}$ & l̀̀ & $\bar{a}$ & pí & ní & sisíà & wā. \\
\hline & woman & ART & COP.NEG & market & in & today & NEG \\
\hline
\end{tabular}

178 'The woman is not in the market'.

\begin{tabular}{|l|l|l|l|l|l|l|l|}
\hline (59b) & L̄ & $\grave{l} \grave{\varepsilon}$ & $\bar{a}$ & pí & ní & dúdúú & wā. \\
\hline & woman & ART & COP.NEG & market & in & always & NEG \\
\hline
\end{tabular}

'The woman is never in the market'. 


\subsection{Postpositional copulas}

\subsubsection{The copula of identification}

The copula of identification (positive polarity) $n \bar{\varepsilon} / n \bar{e} / n \bar{l} /$ mànè occupies the final position in the clause; only the negation particle $w \bar{a}$ can be placed after it.

\begin{tabular}{|l|l|l|}
\hline$(60)$ & Kiō $(\eta)$ & $n \bar{e}$. \\
\hline & house & ICOP \\
\hline
\end{tabular}

'This is a house'.

In Southern San, the copula of identification appears in three synharmonic variants depending on the quality of the preceding vowel (about the vowel harmony, see 2.1). The form of the $3 \mathrm{PL}$ is màncे.

\subsubsection{Negative contrastive copula of identification}

Negative contrastive copula of identification bīe (wā) denotes a negated participant when there is a choice between two possibilities:

\begin{tabular}{|l|l|l|l|l|l|l|}
\hline$(61)$ & Kōò & bie & $w \bar{a}$, & $g \grave{a}$ & $n \bar{\varepsilon}$. & \\
\hline & hen & ICOP.NEG & NEG & guinea.fowl & ICOP & \\
\hline
\end{tabular}

'It is not a hen, it is a guinea fowl'.

Like copula of identification $n \bar{\varepsilon} / n \bar{e} / n \bar{i}$, it is used in cleft sentences:

\begin{tabular}{|l|l|l|l|l|l|l|l|}
\hline$(62)$ & Koodé & $b \bar{i} \bar{e}$ & $a$ & $y \bar{a}$ & $m i ́$ & $w \bar{a}$. & \\
\hline & Kodé & ICOP.NEG & 3SG.PRF & beer & drink & NEG \\
\hline
\end{tabular}

'Kodé, he did not drink beer (contrary to what was expected)'.

\subsubsection{Copulas of existence}

187 Copulas of existence tán (affirmative) and bānbāy (negative) usually also occupy the final position in the clause (see (71) for an exception).

\begin{tabular}{|l|l|l|}
\hline (63) & Lāwà & tán. \\
\hline & God & COP \\
\hline
\end{tabular}

‘God exists’. 


\begin{tabular}{|l|l|l|l|l|l|}
\hline$(64)$ & Bòyó(y) & $\bar{a}$ & wùrù & bāybāy. & \\
\hline & Boyo & POSS & field & COP.NEG & \\
\hline
\end{tabular}

'Boyo has no field (Boyo's field does not exist)'.

\subsubsection{Auxiliary verb gōã in the copular function.}

The auxiliary verb gō $\bar{\alpha}$ (see 3.4.1.) is used to shift a situation to the past or future:

\begin{tabular}{|l|l|l|l|l|}
\hline (65) & Bòyó( $\eta$ & gò̀à & wùrù-d $\bar{\varepsilon} n \bar{a} \bar{a}$ & $l \bar{\varepsilon} \bar{a}$. \\
\hline & Boyo/PFV & stay.PFV & field-owner & EQUAT \\
\hline
\end{tabular}

‘Bojo was (once) a field owner'.

\begin{tabular}{|l|l|l|l|l|l|l|l|l|}
\hline (66) & Kiō̄j & gólé & $k \grave{\varepsilon}$ & gònóy & $n \bar{\partial}$ & á & gò̀a & fú. \\
\hline & house & big & this & body & ICOP & 3SG.PFV & stay.PFV & white \\
\hline
\end{tabular}

'This large house was white'.

\begin{tabular}{|c|c|c|c|c|}
\hline (67) & $L \bar{\nu}$ & $g \bar{\partial} \bar{\alpha} \bar{\alpha}$ & pií-n & $w \bar{a}$. \\
\hline & woman & stay.NTR & market-in & NEG \\
\hline
\end{tabular}

193 'The woman was not in the market'.

194 When the situation refers to the future, the imperfective form is used with the PM tá / $a$ and the future marker $r \bar{e}(68)$ or $n \bar{\partial} / \bar{\eta}$ :

\begin{tabular}{|l|l|l|l|l|l|l|l|}
\hline$(68)$ & Kiōy & $k \grave{\varepsilon}$ & gònóy & tá & $r \bar{e}$ & gò̀̇ & fú. \\
\hline & house & this & body & IPFV.NEW & FUT & stay.IPFV & white \\
\hline
\end{tabular}

195 'This house will be white'.

\begin{tabular}{|c|c|c|c|c|c|}
\hline (69) & Zóǹ & $k \grave{\varepsilon}$ & $\bar{y}$ & $g \grave{\partial} \dot{\varepsilon}$ & bI⿳亠㐅冋 \\
\hline & holiday & this & COP.IPFV & stay.IPFV & tomorrow \\
\hline
\end{tabular}

'The holiday will be tomorrow' 


\subsection{Types of non-verbal sentences}

\subsubsection{Constructions with one argument}

\subsubsection{Existential construction}

\subsubsection{Constructions with two arguments}

\subsubsection{Qualitative constructions attribute a quality to the NP}

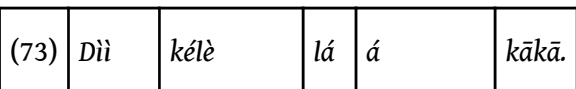




\begin{tabular}{|l|l|l|l|l|l|}
\hline & climb & mountain & on & COP.NEW & hard \\
\hline
\end{tabular}

'Climbing the mountain is hard'.

\begin{tabular}{|l|l|l|l|l|l|l|}
\hline (74) & Kiōō & $k \grave{\varepsilon}$ & gònón & $b \bar{a}$ & fú & wà. \\
\hline & house & this & body & COP.NEG & white & NEG \\
\hline
\end{tabular}

209 'This house is not white'.

\subsubsection{Quantificational constructions}

210 Quantificational constructions are similar to the qualitative ones.

211 (+) NP nə̄ Num

$212(-)$ NP $b \bar{a}$ Num $w \bar{a}$

\begin{tabular}{|l|l|l|l|l|l|}
\hline (75) & Māa & gín & $n \bar{\partial}$ & màn & sì. \\
\hline & 1SG-POSS & $\operatorname{dog}$ & COP & thing & four \\
\hline
\end{tabular}

'My dogs are four' (where mày is a classifier).

\subsubsection{Equative constructions}

214 Equative constructions state the identity of two NP. These constructions use the comitative group ká ... ne /ne/ni:

215 a) Complete equative constructions state the identity of the two NPs.

216 (+) NP1 nə̄ ká NP2 nE

$217(-)$ NP $b \bar{a}$ NP2 $w \bar{a}$

\begin{tabular}{|l|l|l|l|l|l|l|l|l|l|}
\hline (76) & Būrkíná & Fàsò & $\bar{a}$ & kīwī & gōlé & $\bar{y}$ & ká & Wòdóó & né. \\
\hline & Burkina & Faso & POSS & village & large & COP & COMIT & Ouaga & in \\
\hline
\end{tabular}

218 'The capital of Burkina Faso is Ouagadougou'.

219 b) Situational equativity. These constructions are similar in form and meaning to ascriptive ones. Copulas coincide with imperfective markers (both polarities). NP2 is followed by the postposition $l \bar{\varepsilon} \bar{a}$ 'like, alike’. ${ }^{19}$

(+) NP1 tá, (nō) NP2 lē̄a

221

(-) NP1 bā NP2 lē $\bar{a} w \bar{a}$ 


\begin{tabular}{|l|l|l|l|l|l|}
\hline (77) & Bálá & lı̀ & á & là & $l \bar{\varepsilon} \bar{a}$. \\
\hline & field & ART & COP.NEW & profit & EQUAT \\
\hline
\end{tabular}

'Individual field is a profit'.

\begin{tabular}{|c|c|c|c|c|c|}
\hline (78) & $B \bar{\varepsilon}$ & tūmàà & $\bar{y}$ & $d i ́$ & $l \bar{\varepsilon} \bar{a}$. \\
\hline & this & all & COP & work & EQUAT \\
\hline
\end{tabular}

'All this is work'.

\subsubsection{Ascriptive constructions}

Ascriptive constructions express the inclusion of the referent of a NP into a particular class. They use the copula $n \bar{\partial}$ and a postpositional group with $l \bar{\varepsilon} \bar{a}$.

(+) NP1 nə̄ NP2 lē $\bar{a}$

(-) NP1 bā NP2 lēa $w \bar{a}$

\begin{tabular}{|l|l|l|l|l|l|}
\hline (79) & Márti & $\bar{\eta}$ & $m \bar{a}-\bar{a}$ & $n \bar{\varepsilon} l o ́$ & $l \bar{\varepsilon} \bar{a}$. \\
\hline & Martha & COP & 1SG-POSS & daughter & EQUAT \\
\hline
\end{tabular}

'Martha is my daughter'.

\begin{tabular}{|l|l|l|l|l|}
\hline$(80)$ & Sálífù & $\bar{y}$ & lànd $\bar{a}-d \bar{\varepsilon} n \bar{a} \bar{a}$ & $l \bar{\varepsilon} \bar{a}$. \\
\hline & Salif & COP & tradition-owner & EQUAT \\
\hline
\end{tabular}

'Salif is a connoisseur of traditions'.

\begin{tabular}{|l|l|l|l|l|l|}
\hline (81) & Bòyó(y) & $b \bar{a}$ & fừ̀ & $l \bar{\varepsilon} \bar{a}$ & wà. \\
\hline & Boyo & COP.NEG & blacksmith & EQUAT & NEG \\
\hline
\end{tabular}

229 'Boyo is not a blacksmith'.

\subsubsection{Construction of specification:}

(+) NP1 nə̄ ká NP2 nE

231

(-) NP1 bā ká NP2 ne wā 


\begin{tabular}{|l|l|l|l|l|l|}
\hline$(82)$ & Fùù̃ & $\bar{y}$ & $k a ́$ & Bòyó(y) & né. \\
\hline & smith & COP & COMIT & Boyo & in \\
\hline
\end{tabular}

232 'The smith is Boyo'.

\begin{tabular}{|l|l|l|l|l|l|l|}
\hline$(83)$ & $M \bar{a}-\bar{a}$ & $n \bar{\varepsilon} l o ́$ & $\bar{y}$ & $k a ́$ & Mārtì & $n i ́$. \\
\hline & 1SG-POSS & daughter & COP & COMIT & Martha & in \\
\hline
\end{tabular}

233 'My daughter is Martha'.

\subsubsection{Locative constructions}

Locative constructions code the location of the referent designated by the subject NP.

(+) NP1 tá, nə̄ Loc

236

(-) NP1 bā Loc wā

\begin{tabular}{|l|l|l|l|l|}
\hline$(84)$ & Lo & tá & pí & ní. \\
\hline & woman & COP.NEW & market & in \\
\hline
\end{tabular}

237 'The woman is in the market'.

\begin{tabular}{|l|l|l|l|l|l|}
\hline$(85)$ & Lo & $b \bar{a}$ & pií & $n i ́$ & $w \bar{a}$. \\
\hline & woman & COP.NEG & market & in & NEG \\
\hline
\end{tabular}

238 'The woman is not in the market'.

\begin{tabular}{|c|c|c|c|c|c|c|c|}
\hline (86) & $M \bar{a} \bar{a}$ & $n \bar{\varepsilon} l o ́-\eta$ & tá & kùn & 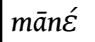 & $m \bar{a} \bar{a}$ & kiō̄. \\
\hline & 1SG.POSS & daughter-PL & COP.NEW & together & 1SG.in & 1SG.POSS & house \\
\hline
\end{tabular}

239 'My daughters are with me in my house'.

\subsubsection{Temporal constructions}

240 Temporal constructions are variants of the locative type: 


\begin{tabular}{|l|l|l|l|l|l|l|}
\hline$(87)$ & Zóñ & $k \grave{\varepsilon}$ & $b \bar{a}$ & $l \grave{\varepsilon}$ & bóé & $w \bar{a}$. \\
\hline & holiday & this & COP.NEG & year & return.NMLZ & NEG \\
\hline
\end{tabular}

'The festival will not take place next year'.

\subsubsection{Possessive constructions}

San Maka has two possessive constructions: a construction with the copula of existence (the type «Boyo's father exists») and postpositional constructions ("locative" type). In this respect San-Maka is closer to the languages of the Southern Mande group (Fedotov, 2016). According to the classification of Leon Stassen (2009), these are "adnominal possessive constructions", which he classified as an " additional type ", in other words, as a typologically rather rare type of possessive constructions.

A) Adnominal possessive constructions in San-Maka are similar to existential structures (with the copulas of existence tán (+) and bāybāy (-)):

(+) NP1 NP2 tán

\section{(-) NP1 NP2 bāybāy (wā)}

\begin{tabular}{|l|l|l|l|l|l|}
\hline$(88)$ & Bòyó(y) & $\bar{a}$ & $k i \bar{o}(\eta)$ & $b \bar{a} \eta \bar{a} \eta$. & \\
\hline & Boyo & POSS & house & COP.NEG \\
\hline
\end{tabular}

'Boyo has no house (lit. Boyo's house does not exists)'.

\begin{tabular}{|l|l|l|l|l|l|}
\hline (89) & Bòyó(y) & $\bar{a}$ & nēló & páá & táñ. \\
\hline & Boyo & POSS & daughter & two & COP \\
\hline
\end{tabular}

'Boyo has two daughters'.

B) Pospositional constructions. According to Stassen's classification, such structures are viewed as « locative » (locational). In San-Maka these constructions use:

1) the postposition log which is not etymologized on the synchronic level;

2) the postposition gōy which is derived from a noun meaning 'hand'.

Constructions with the postposition lò :

(+) NP1 nō, tá NP2 lò̄

(-) NP1 bā NP2 lṑ̀ wā

\begin{tabular}{|l|l|l|l|l|}
\hline (90) & Wùrù & tá & Bòyó(y) & lò̄y. \\
\hline & field & COP.NEW & Boyo & in.possession \\
\hline
\end{tabular}




\begin{tabular}{|l|l|l|l|l|l|}
\hline (91) & Wóró & $b \bar{a}$ & $m \bar{a}$ & lòn & $w \bar{a}$. \\
\hline & money & COP.NEG & 1SG & in.possession & NEG \\
\hline
\end{tabular}

255 'I have no money (on me)'.

256 Constructions with the postposition gōy:

(+) NP1 nə̄,tá NP2 gōy

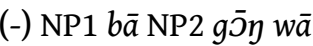

The adnominal possessive constructions express permanent possession and are used more often with the kinship terms or other objects of permanent possession (the possessor is a "legal" owner). Pospositional constructions with lō are used more often to indicate abstract possession; gōy co-occurs with more concrete items or designates a situational possession:

\begin{tabular}{|l|l|l|l|l|l|l|l|l|l|}
\hline (92) & Wóró & tá & $m \bar{a}$ & lò̄ & $\overline{p i c ̀, ~}$ & sćnē & wóró & bā & $m \bar{a}$ \\
\hline & money & COP & $1 \mathrm{SG}$ & in.possession & at.home & but & money & COP.NEG & $1 \mathrm{SG}$ \\
\hline
\end{tabular}

\begin{tabular}{|l|l|l|l|}
\hline & gōy & kànáá & wā. \\
\hline & hand & here & NEG \\
\hline
\end{tabular}

'I have money at home but I have no money on me here'.

The loss of the lexical meaning in the postposition lon in San-Maka has led to the emergence of a new construction built according to the same model.

Constructions used in non-verbal sentences of Southern San are represented in Table 8.

Table 8. Constructions of non-verbal sentences of San-Maka

\begin{tabular}{|c|c|c|}
\hline Form & Predicative element & Meaning \\
\hline $\begin{array}{l}\text { táy (+), } \\
\text { bāybāy (-) }\end{array}$ & copulas of existence & $\begin{array}{l}\text { existentional, adnominal possessive } \\
\text { constructions }\end{array}$ \\
\hline $\begin{array}{l}n \bar{\varepsilon} \quad(n \bar{e}, \quad \bar{i}, \\
\text { mànc̀) }(+) \\
\text { biè (-) }\end{array}$ & copula of identification & construction of identification \\
\hline $\begin{array}{l}\text { tá (+) } \\
n \bar{\partial} \quad(+) \quad \text { Adj } \\
(\text { Num) } \\
b \bar{a} w \bar{a}(-)\end{array}$ & imperfective PM in copular function & qualitative, quantitative constructions \\
\hline
\end{tabular}




\begin{tabular}{|c|c|c|}
\hline $\begin{array}{l}\text { tá(+) } \\
n \bar{\partial}(+) \mathrm{NP}+ \\
\text { postp } \\
b \bar{a} w \bar{a}(-)\end{array}$ & $\begin{array}{l}\text { imperfective PM in copular function with } \\
\text { postpositional group }\end{array}$ & $\begin{array}{l}\text { locative, temporal, possessive } \\
\text { constructions }\end{array}$ \\
\hline$n \bar{\partial}+k a ́ \mathrm{NP} n \varepsilon ́$ & $\begin{array}{l}\text { imperfective PM in copular function with } \\
\text { the comitative frame construction } k a ́ \text {... né }\end{array}$ & $\begin{array}{l}\text { (complete) equative and specificative } \\
\text { constructions }\end{array}$ \\
\hline$n \bar{\partial}+\mathrm{NP} l \bar{\varepsilon} \bar{a}$ & $\begin{array}{l}\text { imperfective } \mathrm{PM} n \bar{\partial} \text { in copular function } \\
\text { with postpositional group (postposition } \\
l \bar{\varepsilon} \bar{a} \text { ) }\end{array}$ & $\begin{array}{l}\text { (situational) equative, ascriptive } \\
\text { constructions }\end{array}$ \\
\hline
\end{tabular}

As shown in the Table 8, the most widely used constructions are structures with postpositions, which are, in fact, constructed by analogy with the locative construction.

\section{Conclusion}

The overview of verbal and non-verbal sentences in San-Maka shows that there is a parallelism between constructions of the imperfective zone: the imperfective predicative markers of both polarities are linked to the corresponding copulas; they coincide in form and express similar meanings.

Copulas which coincide with predicative markers:

- imperfective affrimative $n \bar{\partial} / \bar{y} / m \bar{a}$;

- imperfective affrimative (new information) tá /á;

- imperfective negative $b \bar{a} / \bar{a}(w \bar{a})$.

There are also specific predicative markers which are not directly connected to any copula. These are:

267 - perfective affirmative ná / high tone on the final vowel of the Subject NP;

268 - perfective experientive bì (wa));

269 - imperfective negative in dependant clauses, prohibitive bāràn (wā).

270 There are also specific copulas:

271 Copulas of identification:

- affirmative $n \bar{\varepsilon} / n \bar{\varepsilon} / n \bar{i} / \operatorname{man} \overline{\bar{\varepsilon}}$;

- negative bie (wā);

272 Copulas of existence:

- affirmative táñ

- negative bāybāy.

273 There is certain parallelism in form and meaning between negative copulas and

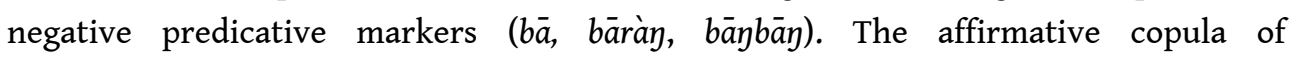
identification $n \bar{\varepsilon} / n \bar{\varepsilon} / \bar{n} \bar{i} / m \bar{a} n \bar{\varepsilon}$ seem to be etymologically connected to the imperfective copula $n \bar{\partial} / \bar{y} /$ māy. It is worth mentioning that a focus marker $-\eta{ }^{20} /$ māy (3PL) seem to be related to the copula of identification.

274 For further research on the origin of these word classes of San-Maka, a comparison with data of other languages of the San cluster is necessary. 


\section{Abbreviations}

\begin{tabular}{|l|l|}
\hline $1-1$ st person & N - noun \\
$2-2^{\text {nd }}$ person & NEG - negation \\
$3-3$ rd person & NEW - new information \\
Adj - adjective & NMLZ - nominalized form \\
Art - article & NTR - neutral form \\
Aux - auxiliar & Num - numeral \\
COMIT - comitative & DO - direct object \\
COP - copula & IO - indirect object \\
Dem - demonstrative & Pl - plural \\
EMPH - emphatic pronoun & PM - predicative marker \\
EQUAT - equative postposition & POSS - possessive preposition \\
EXP - experientive & PRF - perfective \\
FUT - future & PROH - prohibitive \\
H - hign tone & PROX - proximate \\
ICOP- copula of identification & RECP - reciprocal \\
IMP - imperative & S - subject \\
IPFV - imperfective & Sg - singular \\
L - low tone & V - verb. \\
\hline
\end{tabular}

\section{BIBLIOGRAPHY}

Berthelette, John. 2001 Survey Report on the San (Samo) language. SIL. https://www.sil.org/ resources/archives/8983

Boo nen séwe. San-Fransi. Fransi-San [Lexique san-français, français-san]. 2003. Ouagadougou : SIL. Burkina Faso.

Ebermann, Erwin. Sane subclassification (map, manuscript).

Fedotov, Maxim. 2016. Adnominal predicative possessive construction and pragmatically "flexible" noun phrases in Gban. Studies on African languages 6. [Issledivanija po jazykam Afriki 6]. Moscow : Kliuch-C, pp. 320-345.

Greenberg, Joseph H. 1963. The Languages of Africa. International journal of American linguistics, $29: 1$, part 2,

Guide d'orthographe san macaa. Édition préliminaire. SIL. 
Guide d'orthographe san mayaa. Édition préliminaire - juin 2011. SIL.

Ka daa wJ San sÉwe pe. 1-2. Syllabaire en langue San (1-2). Ouagadougou: ANTBA, 2003.

Paré, Moise. 1999. Derivation, composition et syntagmes nominaux en san (parler de Yaba). Rapport de D.E.A. Université d'Ouagadougou,

Paré, Moi ise. 1998. L'énoncé verbal en san (parler de Yaba). Mémoire de maîtrise. Université de Ouagadougou.

Platiel, Susanne. 1974. Description du parler samo de Toma, Haute-Volta. Phonologie, syntaxe. Thèse pour le doctorat d'Etat.

Prost, André. 1981. De la parenté des langues busa-boko avec le bisa et le samo. Mandenkan; 2, pp. 17-29.

Stassen, Leon. 2009. Predicative possession. Oxford studies in Typology and linguistic theory. Oxford : Oxford University Press.

Vydrine, Valentin; Ted Bergman; Matthew Benjamin. 2001. Mandé Language Family, East, EasternEastern, Bisa, San and Sane. SIL. http://www-01.sil.org/silesr/2000/2000-003/bisa_san.htm

Welmers, William. The Mande languages. 1958. Georgetown Univ. Monograph Series on Languages and Linguistics, 11, pp. 9-24.

\section{NOTES}

1. Each dictionary contains an orthographic guide and a text sample.

2. Macaa reflects the pronunciation [matfaa].

3. The purple points on the Ebermann's map are Fula-speaking villages of the so-called rimaibé, ethnic San-Maya who have switched to Fula.

4. In this article, vocalic nasalization is marked with tilda below the letter.

5. The final $y$ designates the floating nasal element (see below).

6. In order to distinguish the floating nasal element from the final nasal vowel $-\mathfrak{y}$, it is designated (y) (in brackets) in this article.

7. The citation form of the verb is the Imperative which obscures the inital tone of transitive verbs, as in the presence of a non-pronominal direct object verbs raise their tones.

8. Tô is a very common dish in Burkina Faso, consisting of cooked millet or sorghum flour. It is served as a paste and is eaten with a sauce.

9. A variant $m \bar{a}$ is used in some varieties.

10. In Platiel's work, $/ \bar{\sim} /$ is the sign designating the nasal vowel $\eta$.

11. This fact was mentiond by Paré (1998: 61), but he did not consider it the main distinctive feature.

12. According to M. Paré (1998: 63), constructions with the PM bie encode "progressif négatif" and "indique que le process n'est pas en cours de réalisation".

13. A pronominal object (indirect or direct inanimated) of the $3 \mathrm{Sg}$ is usually omitted; in this case the subsequent postposition or verb aquire a low tone.

14. Comment of an activist of the San literacy company: "It often happens".

15. M. Paré (1998: 41) considers the sequence bāà rē to be an auxiliary but notes that the element $\overline{r e}$ is optional. In my data, only the variant with $\overline{r e}(b \bar{a} a ̀ r \bar{e})$ is attested.

16. On the contrary, the periphrastic construction of the Immediate Future uses the PP $\bar{\eta} / n \bar{\partial}$ with the imperfective form of the verb dāa 'to come', see ex. (44).

17. When used as copulas they are glossed as COP. 
18. Constructions with different copulas ( $n \bar{\partial}$ or tá) have different informational structure, see 3.2.2.

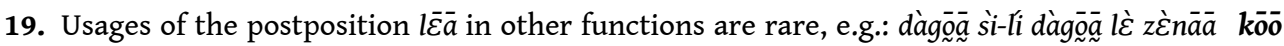
gìi $\mathbf{l} \overline{\boldsymbol{\varepsilon}} \overline{\boldsymbol{a}}$ 'The fetish-maker made a fetish like an egg'.

20. The focus marker $-\eta$ is a clitic.

\section{ABSTRACTS}

This article presents an overview of the basic verbal constructions of San-Maka, an East Mande language of Burkina Faso. The introduction provides general facts on San-Maka: its position in the San / Sane language cluster, basic information on its phonological (segmental and tonal) system. Information on noun and pronoun morphology is also given. The main part of the article deals with predicative constructions of San-Maka. The morphological paradigm of a verb in SanMaka consists of three aspectual forms: neutral, perfective and imperfective. Perfective and imperfective verb forms combine with predicative markers, some of which seem derived from copulas. The grammatical meaning of the existing predicative constructions is analyzed. It is shown that two imperfective constructions differ by their information structure and reflect different pragmatic intentions of the speaker. The final section represents an overview of SanMaka non-verbal predications. The Conclusion shows some similarities between grammatical words in San-Maka: certain copulas, predicative markers and the focus marker.

L'article présente un aperçu des constructions verbales de base en san-maka, une langue Mandé du Burkina Faso. L'introduction fournit des faits généraux sur le san-maka : sa position dans le groupe San-Sane, le système phonologique segmental et tonal, la morphologie des noms et des pronoms. La partie principale de l'article traite des constructions prédicatives de san-maka. Le paradigme morphologique du verbe se compose de trois formes aspectuelles : neutre, perfective (accomplie) et imperfective (inaccomplie). Les formes accomplie et inaccomplie se combinent avec des marqueurs prédicatifs, dont certains semblent être dérivés des copules. Les valeurs grammaticales des constructions prédicatives sont analysées. Il est montré que les deux constructions imperfectives disponibles en san-maka diffèrent par leurs structures d'information et par les intentions pragmatiques du locuteur. La section finale traite des prédications nonverbales. Dans la conclusion, des similitudes entre certains mots grammaticaux (copules, marqueurs prédicatifs, la marque de focalisation) sont discutées.

В СТАТЬЕ ПРЕДСТАВЛЕН ОБЗОР ОСНОВНЫХ ПРЕДИКАТИВНЫХ КОНСТРУКЦИЙ В САН-МАКА, ЯЗЫКЕ ВОСТОЧНОЙ ГРУППЫ СЕМЬИ МАНДЕ, РАСПРОСТРАНЕННОМ В БУРКИНЕ-ФАСО. ВВЕДЕНИЕ СОДЕРЖИТ ОБЩИЕ СВЕДЕНИЯ О ЯЗЫКЕ: ЕГО ПОЛОЖЕНИЕ В ЯЗЫКОВОМ КЛАСТЕРЕ САН-САНЕ, ИНФОРМАЦИЯ О ФОНОЛОГИЧЕСКОЙ И ТОНАЛЬНОЙ СИСТЕМАХ ДАННОГО ЯЗЫКА. ДАЛЕЕ ПРИВОДИТСЯ БАЗОВЫЕ ДАННЫЕ О МОРФОЛОГИИ СУЩЕСТВИТЕЛЬНОГО И МЕСТОИМЕНИЯ. ОСНОВНАЯ ЧАСТЬ СТАТЬИ ПОСВЯЩЕНА АНАЛИЗУ ПРЕДИКАТИВНЫХ КОНСТРУКЦИЙ ЯЗЫКА САНМАКА. МОРФОЛОГИЧЕСКАЯ ПАРАДИГМА ГЛАГОЛА В ЭТОМ ЯЗЫКЕ СОСТОИТ ИЗ ТРЕХ АСПЕКТУАЛЬНЫХ ФОРМ: НЕЙТРАЛЬНОЙ, ПЕРФЕКТИВНОЙ И ИМПЕРФЕКТИВНОЙ. ПЕРФЕКТИВНЫЕ И ИМПЕРФЕКТИВНЫЕ ФОРМЫ СОЧЕТАЮТСЯ С ПРЕДИКАТИВНЫМИ ПОКАЗАТЕЛЯМИ, НЕКОТОРЫЕ ИЗ КОТОРЫХ, ПО-ВИДИМОМУ, ВОСХОДЯТ К СООТВЕТСТВУЮЩИМ СВЯЗКАМ. ДАЕТСЯ АНАЛИЗ ГРАММАТИЧЕСКОЙ СЕМАНТИКИ ИМЕЮЩИХСЯ ПРЕДИКАТИВНЫХ КОНСТРУКЦИЙ. ПОКАЗАНО, ЧТО 
ДВЕ СИНОНИМИЧНЫЕ ИМПЕРФЕКТИВНЫЕ КОНСТРУКЦИИ РАЗЛИЧАЮТСЯ ПО ИНФОРМАЦИОННОЙ СТРУКТУРЕ И ОТРАЖАЮТ ПРАГМАТИЧЕСКИЕ НАМЕРЕНИЯ ГОВОРЯЩЕГО. ПОСЛЕДНИЙ РАЗДЕЛ ПОСВЯЩЕН ОБЗОРУ НЕВЕРБАЛЬНЫХ ПРЕДИКАЦИЙ САН-МАКА. В ЗАКЛЮЧЕНИИ ПОКАЗАНО МАТЕРИАЛЬНОЕ СХОДСТВО МЕЖДУ НЕКОТОРЫМИ СЛУЖЕБНЫМИ СЛОВАМИ: НЕКОТОРЫМИ СВЯЗКАМИ, ПРЕДИКАТИВНЫМИ ПОКАЗАТЕЛЯМИ И МАРКЕРОМ ФОКУСА.

\section{INDEX}

motsclesru ЯЗЫКИ МАНДЕ, КЛАСТЕР САН, САН-МАКА, ГЛАГОЛ, АСПЕКТ, ПРЕДИКАТИВНЫЕ КОНСТРУКЦИИ, НЕГЛАГОЛЬНАЯ ПРЕДИКАЦИЯ, ИНФОРМАЦИОННАЯ СТРУКТУРА

Mots-clés: mandé, san, san-maka, aspect, verbe, constructions prédicatives, prédication nonverbale, structure d'information

Keywords: Mande cluster, San, San-Maka, verb, aspect, predicative constructions, non-verbal predication, informational structure

\section{AUTHOR}

\section{ELENA PEREKHVALSKAYA}

Institut de recherches linguistiques Académie des Sciences de la Russie St. Petersburg State University elenap96@gmail.com 